\title{
TRANSPARENCY IN CONDITIONS OF CZECH FOUNDATION'S MANAGEMENT
}

\author{
[Transparentnost v podmínkách řízení českých nadací]
}

\author{
Marek Jošt ${ }^{1}$ \\ ${ }^{1}$ Vysoká škola ekonomická v Praze, Fakulta financí a účetnictví, nám. Winstona Churchilla 4,130 67 Praha 3 \\ Email: marek.jost@vse.cz.
}

\begin{abstract}
The article deals with analysis of Czech foundations' management transparency in the area of accounting and auditing. The foundations that have received contributions from the Investment Fund for Foundations are compared with the foundations that have not received such contributions. The main aim of this article is to assess if release of legislation regarding foundations in the Czech Republic, which has been in force since 2014, is appropriate. This includes, in particular, the Act on Foundations and Endowment Funds, and the termination of contracts for the transfer of contributions from the Investment Fund for Foundations to foundations. The results of the research can be used for further analyses of the impact of the new legislation on the transparency of foundations, as well as for discussion about the future form of laws regulating activities of foundations in the Czech Republic.
\end{abstract}

Keywords: audit, foundation, investment fund for foundations, transparency.

JEL classification: M41, M42

Doručeno redakci: 27.10.2017; Recenzováno: 6.11.2017; 7.11.2017; Schváleno k publikování: 13.12.2017

\section{Úvod}

Nadace patř́ spolu s dalšími neziskovými organizacemi do skupiny tzv. nestátních neziskových organizací (dále také „NNO“), kterých působilo v dubnu 2017 na území České republiky dohromady 129947 (Neziskovky.cz 2017). NNO zaměstnávaly v roce 201254226 pracovníků a pracovalo pro ně ve stejném roce 25964 dobrovolníků. Produkce NNO dosáhla v roce 2012 56,21 mld. Kč a podíl na tvorbě hrubého domácího produktu v období let 2008 až 2012 dosáhl $0,55 \%$. NNO přijaly $\mathrm{v}$ roce 2015 dotace $\mathrm{z}$ veřejných rozpočtů $\mathrm{v}$ částce 16,5 mld. Kč (Prouzová 2015).

Přestože na nadace připadá pouhý $0,4 \%$ podíl $\mathrm{z}$ celkového počtu $\mathrm{NNO}$, jejich role ve společnosti nabývá na významu, zejména s ohledem na výši spravovaných prostř̌edků a každoročně rozdělené nadační př́spěvky. S tím souvisí potřeba dohlížet na jejich činnost, aby se minimalizovalo riziko možného zneužití těchto subjektů $\mathrm{k}$ legalizaci výnosů $\mathrm{z}$ trestné činnosti a financování terorismu, což je problém, s nímž se dnešní svět bohužel poměrně často potýká.

Otázce transparentního hospodaření českých nadací bylo věnováno již mnoho diskuzí, jejichž závěry obvykle poukázaly na její nízkou míru. Př́stupy k měření a hodnocení transparentnosti se obvykle liší v závislosti na tom, co je předmětem analýzy a jaká kritéria transparentnosti jsou použita. V návaznosti na to se liší pochopitelně i získané výsledky a vyslovený názor.

Cílem článku je analyzovat kritéria transparentnosti hospodaření českých nadací v oblasti účetnictví a auditu, která vyplývají z dnes již neúčinného Zákona o nadacích a nadačních fondech za dvě skupiny nadací a následně posoudit, zda existují na úrovni transparentnosti významné rozdíly mezi oběma těmito skupinami. První analyzovaný soubor nadací představují nadace príijemci prííspěvků z Nadačního investičního fondu (dále také „NIF“) a 
druhý soubor pak náhodně vybrané ostatní nadace bez těchto prostředků. Dílčím cílem je pak posouzení vhodnosti uvolňování české nadační legislativy, k níž v posledních letech dochází také v evropském měřítku. Druhý dílčí cíl spočívá ve zhodnocení procesu kapitalizace českých nadací prostřednictvím Nadačního investičního fondu a posouzení vhodnosti ukončování smluv o převodu prostředků z Nadačního investičního fondu uzavřených $\mathrm{v}$ minulosti mezi státem a vybranými nadacemi.

První část článku se věnuje vymezení pojmu „transparentnost“ a zmiňuje také jiné výzkumy provedené na poli transparentnosti hospodaření nadací, popř. jiných organizací občanské společnosti, mezi něž patř́i i nadace. Závěry těchto výzkumů posloužily ke stanovení hypotéz, jejichž platnost je ověřována $\mathrm{v}$ empirické části článku pomocí Z-testu rovnosti dvou výběrových poměrů.

\section{Vymezení pojmu transparentnost}

Pospíšil (2006) v souvislosti s transparentností uvádí, že i když je princip transparentnosti obecně uznáván, tak v praxi českých neziskových organizací vyvstávají určité problémy. První z nich vidí v nevyjasněnosti obsahu pojmu transparentnost a $\mathrm{z}$ toho plynoucí bezradnost při jeho aplikaci. Dále poukazuje na nedostatek objektivních údajů a poznatků o situaci v neziskovém sektoru a chybějící diskuzi, z níž by vyplynuly požadavky na legislativu, která by oddělila diskuzi o transparentnosti od diskuze o výkaznictví. Podle Pospíšila se v úvahách o transparentnosti kombinují dva principy, a to průhlednost a odpovědnost, přičemž termín průhlednost je širší než termín odpovědnost a je mu nadřazen.

Jakubka (In Kroupa 2006) rozděluje transparentnost do několika skupin, a to na transparentnost poslání a cílů, transparentnost aktivit organizace, finanční transparentnost, transparentnost vedení a řízení a transparentnost vztahů s okolním světem. Je zřejmé, že termín transparentnost je možné definovat různě v závislosti na tom, co je cílem zkoumání a jaká kritéria se k měření transparentnosti používají.

Neziskové organizace, mezi něž patří nadace, jsou zakládány ve vyspělých zemích západní civilizace na základě práva svobodného sdružování občanů zakotveného většinou v ústavě. Jejich odpovědnost je orientována vůči věřitelům, př́jemcům služeb, zaměstnancům, státu, dárcům a veřejnosti a transparentnost $\mathrm{u}$ nich hraje mnohem větší roli, než u soukromých podnikatelských subjektů. Přesto je často zřejmé, že tyto hodnoty neziskovým organizacím schází (Wyatt, nedatováno).

Transparentnost má obvykle kvalitativní charakter a lze ji obtížně měřit. Mnohdy je potřeba hodnotit několik faktorů zároveň a posuzovat jejich vývojové tendence v čase, přičemž je nutné zohlednit i důležitost jednotlivých faktorů ve srovnání s ostatními a přisoudit jim váhy. Je jasné, že pokud by předmětem zkoumání byla transparentnost z pohledu konkrétního subjektu, pak by se vybraná kritéria jejího měření subjekt od subjektu lišila a stejně tak učiněné závěry. Nebylo by tedy možné učinit obecný spolehlivý názor, zda je nebo není daná nadace transparentní. $Z$ tohoto důvodu jsou předmětem analýzy kritéria transparentnosti zakotvená $\mathrm{v}$ původním Zákoně o nadacích a nadačních fondech, která jsou obecně platná a nesporná a vztahují se k celému procesu fungování nadací ve třech fázích: přijetí prostředků jejich správa - rozdělování nadačních př́íspěvků.

Pro účely tohoto článku lze definovat transparentnost hospodaření jako ochotu a schopnost naplňovat požadavky, které jsou kladeny na nadace legislativními či jinými předpisy (nebo také smlouvami), prř́padně jinými subjekty v souvislosti s jejich činností, prostřednictvím 
zveřejňování volně dostupných informací v různé podobě. Transparentnost je možné dále zvyšovat zveřejňováním informací nad rámec legislativně či smluvně definovaných požadavků.

\section{Výzkumy v oblasti transparentnosti nadací}

Tématu transparentnosti českých nadací se dosud věnovalo jen několik málo vědeckých prací a studií, avšak mnohé z nich upozorňují na její neuspokojivou míru. Např́ílad Bachman (2012) vidí problém v nízkém podílu nadací, které zveřejnily svou výroční zprávu na svých webových stránkách $(41,8 \%$ nadací) a $\mathrm{z}$ toho pouhá polovina ji také poskytla rejstř́kovému soudu. Obdobná situace podle něj platí v př́ípadě zveřejňování statutu na webových stránkách $(32,7 \%$ nadací), grantových pravidel $(36,4 \%$ nadací), informací o povinném auditu (30,9\% nadací) a pravidla omezujícího správní náklady (10,9\% nadací). Tyto závěry vyplynuly z výzkumu, který prováděl metodou obsahové analýzy webových stránek neziskových organizací v období od srpna 2011 až do záŕí 2012. Statistický soubor zahrnoval 100 náhodně vybraných nadací, z nichž jen 55 \% vlastnilo webové stránky, a pouze ty byly zahrnuty do výzkumu.

Mnohem rozsáhlejší výzkum prováděla Katedra manažerského účetnictví Fakulty financí a účetnictví Vysoké školy ekonomické v Praze ve spolupráci s Informačním střediskem Mikuláš, o. p. s. v roce 2007. Ten se zaměřil na výroční zprávy nadací vydané za roky 2004 až 2006, přičemž statistický soubor čítal 164 nadací. Výzkum se snažil analyzovat, zda sledované nadace dostály v roce 2007 více než osmi tisícům zákonně zveřejňovaných položek. Již v samotném úvodu se uvádí, že z 8036 kritérií bylo splněno 4030 , což představuje $50,15 \%$. Dalších 623 položek $(7,75 \%)$ se pojilo s určitými výhradami a zbylých 3383 položek (42,10\%) nebylo splněno vůbec (Stránský 2007). Toto prvotní zjištění považuje Stránský za nejdůležitější sdělení o transparentnosti nadací a dodává, že i v oblasti, kde má stát rozsáhlé možnosti kontroly, pravděpodobně rezignuje na účinné vymáhání takového jednání soukromých subjektů, které by bylo v souladu se zákonnou úpravou. Jinak si totiž nelze vysvětlit takto problematický výsledek u subjektů, jejichž povinnosti jsou z celého neziskového sektoru nejpřesněji definovány zákonem. Výzkum dospěl k následujícím závěrům:

- každá pátá nadace nezveřejnila bud' statut, nebo výroční zprávu, nebo účetní závěrku za rok 2006; téměř tři čtvrtiny nadací nejsou schopny srozumitelně komunikovat veřejnosti grantová pravidla, což je stěžejní proces v činnosti nadace,

- většina nadací nehodnotí vlastní výkonnost (i když jim to ukládá zákon); poměrně často uvádí slovní hodnocení, ale málokterá nadace pracuje při hodnocení vlastní výkonnosti s měřitelnými údaji,

- míra naplnění zákonných požadavků v oblasti vykazování darů se pohybovala maximálně na úrovni $60 \%$ (někdy i hluboko pod touto hranicí),

- oblast rejstříkových informací o nadacích dosáhla nejlepších výsledků, pravděpodobně proto, že bez zápisu těchto informací do rejstř́íku nemůže nadace vůbec vzniknout; jde o jedinou oblast splněnou na $100 \%$,

- zveřejňování informací obsažených ve statutu je silně zanedbáváno, jelikož dvě třetiny požadavků v této oblasti nejsou vůbec naplněny,

- informace uvedené ve výroční zprávě poukazují také na kvalitu správy nadace managementem, bohužel požadavky $v$ této oblasti nejsou téměř vůbec vykazovány,

- informace o prrijatých darech a poskytnutých prríspěvcích vykazovaly průměrné výsledky, avšak jednotlivé hodnoty byly dosti nesrovnatelné - některé nadace měly nadprůměrné hodnoty a jiné prakticky tyto informace neuváděly vůbec,

- obdobně se vyvíjela i míra vykazování v oblasti hospodaření nadace. 
Závěrečná část výzkumu uvádí, že ve výkaznictví existují propastné rozdíly nejen mezi nadacemi, ale také mezi druhy informací. Míra vykazování se blíží stu procentům jen zdaleka. Nadační sektor se potýká s podobnými neduhy jako podnikatelské subjekty, tedy vykazují spíše dobře uchopitelné údaje s nízkým informačním prínosem na úkor strategických, syntetických a hodnotících informací. Přestože jde o zákonné požadavky, stát je v této oblasti benevolentní.

Stránský (2009) ověřoval platnost teze, předpokládající, že nadace dobře informují veřejnost o dosahované výkonnosti. Ta však nebyla potvrzena. Výsledky testů naopak poukázaly na nízkou míru zveřejňování výročních zpráv v roce 2006 na úrovni $40 \%$. V daném roce tedy většina českých nadací výroční zprávu nezveřejnila a porušila legislativní předpisy. Byly potvrzeny hypotézy předpokládající závislost členství ve Fóru dárců a smlouvy o převodu prostředků z Nadačního investičního fondu uzavřené mezi nadacemi a státem na pravděpodobnosti zveřejnění výroční zprávy. Stránský to zdůvodňuje tím, že nadace s prostředky z Nadačního investičního fondu a členské nadace Fóra dárců si více uvědomují odpovědnost vůči veřejnosti a zavazují se přísně dodržovat platné zákony.

Transparentnosti na úrovni české občanské společnosti, do níž patří i nadace, se věnuje studie realizovaná od prosince 2003 do listopadu 2004 Nadací pro rozvoj občanské společnosti (NROS) ve spolupráci s Fakultou humanitních studií Univerzity Karlovy v Praze v rámci mezinárodního projektu CIVICUS. Do něho se zapojilo 50 zemí a výsledkem je index občanské společnosti (anglicky Civil Society Index). Konkrétně v části věnované průhlednosti (transparentnosti) studie zjišt'uje, nakolik analyzované subjekty podporují a v praxi realizují transparentnost se zaměřením na korupci v občanské společnosti, finanční transparentnost organizací občanské společnosti a jejich aktivity na podporu průhlednosti. V rámci finanční transparentnosti vyplynuly pro nadační subjekty nelichotivé závěry spojené s nízkým podílem těch, které zveřejnily výroční zprávu ve sbírce listin. Pouze necelá třetina z celkového počtu tuto povinnost splnila $\mathrm{v}$ roce 2002 (polovina nadací a necelá třetina nadačních fondů, Vajdová 2005). Vajdová řadí mezi slabé stránky v kapitole „Silné a slabé stránky české občanské společnosti a doporučení do budoucna“ zmíněné studie, zejména neprůhlednost financí a aktivit. Ta podle ní není záměrná, ale je důsledkem toho, že chybí „záměr být transparentní““. Jeden $\mathrm{z}$ důvodů neprůhlednosti spatřuje $\mathrm{v}$ tom, že mnohé organizace nemají personál, který by např. připravil výroční zprávu, ani peníze, aby si její zpracování mohly zadat.

K výrazně lepším závěrům na úrovni zveřejňování výročních zpráv a účetních závěrek nadacemi dospěl Jošt (2016a). Předmětem jeho výzkumu je analýza transparentnosti hospodaření př́ijemců př́íspěvků z Nadačního investičního fondu. Veškerá statistická data vycházejí z výročních zpráv a účetních závěrek dostupných na portálu portal.justice.cz a na webových stránkách 73 nadací a 1 nadačního fondu, tedy všech subjektů, které v minulosti obdržely př́spěvky z Nadačního investičního fondu. Referenčním obdobím jsou roky 2009 až 2013, tedy období, kdy platil ještě Zákon o nadacích a nadačních fondech. Průměrně $86 \%$ sledovaných nadací zveřejnilo v daném období účetní závěrku a až $90 \%$ nadací zveřejnilo výroční zprávu. Naopak problematické se zdá být zveřejňování pravidla omezujícího správní náklady a kontrola jeho dodržování, protože průměrně $30 \%$ nadací nevěnovalo této oblasti vůbec žádnou pozornost. Vzhledem $\mathrm{k}$ tomu, že jde o prŕijemce spravující veřejné zdroje $\mathrm{v}$ částce přesahující 2,5 mld. Kč, daly by se očekávat výrazně lepší hodnoty. Na rostoucí podíl nadací nezveřejňujících informace o provedeném auditu v letech 2009 až 2013 upozorňuje Jošt (2016b) - ten uvádí, že $9,46 \%$ až $12,16 \%$ nadací př́ijemců př́íspěvků z Nadačního investičního fondu nezveřejnilo zprávu auditora nebo výrok auditora k účetní závěrce. 
Audit v českých nadacích podrobněji zkoumal Jošt (2016c), konkrétně zveřejňování zprávy auditora, zveřejňování jména auditora, výroku auditora a odměny za provedený audit. Statistický soubor zahrnoval 100 náhodně vybraných nadací působících v České republice. Veškerá data byla čerpána z účetních závěrek a výročních zpráv nadací zveřejněných na portálu portal.justice.cz a na webových stránkách nadací za roky 2009 až 2013. Zprávu auditora nezveřejnilo v roce 2013 až $31 \%$ nadací (v letech 2009 až $201216 \%$ až $18 \%$ nadací), jméno auditora ve stejném roce nebylo možné dohledat až u $28 \%$ nadací (v letech 2009 až $201214 \%$ až 15\% nadací) a odměnu za audit nezveřejnilo v daném období $82 \%$ až 90 \% nadací. Odměna za audit však nemusela být podle Zákona o nadacích a nadačních fondech ani jiného předpisu zveřejňována. Proto drtivá většina nadací tuto informaci ve výročních zprávách ani účetních závěrkách neuvádí. Všechna kritéria zaznamenala v průběhu období rostoucí trend počtu nadací, které je nezveřejnily.

\section{Hypotézy, metodika, vymezení statistických souborů}

S ohledem na výše uvedené výzkumy a studie a jejich závěry, poukazující vesměs na nízkou míru transparentnosti hospodaření českých nadací, byly stanoveny tyto hypotézy:

Hypotéza 1: Nadace bez prostředků z Nadačního investičního fondu nejsou při své činnosti transparentní.

Hypotéza 2: Mezi nadacemi př́jemci př́íspěvků z Nadačního investičního fondu a nadacemi bez těchto př́íspěvků neexistují na úrovni transparentnosti významné rozdíly.

Vzhledem k tomu, že teprve od 1. ledna 2014 vstoupila v platnost nová legislativa v podobě Nového občanského zákoníku, která poměrně zásadně uvolnila pravidla pro činnost nadací, není zatím k dispozici dostatečné množství dat pro hodnocení vlivu tohoto nového předpisu na transparentnost nadací. V současné době jsou k dispozici účetní závěrky a výroční zprávy za účetní období 2014, 2015 a jen u některých subjektů také za rok 2016, avšak aby analýza měla dostatečnou vypovídací schopnost, zapotřebí by byla časová řada dat alespoň za 5 let. Proto jsou statistická data čerpána za posledních pět let platnosti Zákona o nadacích a nadačních fondech, a to za roky 2009 až 2013. Údaje jsou převzaty z výročních zpráv a účetních závěrek nadací zveřejněných na portálu portal.justice.cz a na webových stránkách nadací. Předmětem analýzy jsou dvě skupiny nadací: nadace př́ijemci příspěvkủ z Nadačního investičního fondu a ostatní nadace bez těchto prostředků. Konkrétně se výzkum zaměřuje na plnění kritérií transparentnosti, která vyplývají z uvedeného zákona oběma skupinami nadací. Výsledky analýz prováděných na úrovni jednotlivých kritérií transparentnosti jsou vyjádřeny jako procento nadací nezveřejňujících sledovanou veličinu z celkového počtu nadací.

Na samém počátku přijalo prostředky z Nadačního investičního fondu celkem 74 subjektů (73 nadací a Nadační fond obětem holocaustu, dále také „NFOH“ - jejich seznam uvádí např. Jošt 2016a). S ohledem na některé důležité skutečnosti však bylo nutné přistoupit k vyloučení vybraných organizací z testovaného souboru. Soubor tvoří z převážné části organizace mající právní formu nadace, proto byl vyloučen „NFOH“. Dále z informací Ministerstva financí České republiky („MFČR“) vyplynulo, že dvě nadace př́spěvek vrátily, a to Nadace Patriae a Nadace Křižovatka. Nadace BOHEMIAE se nachází od roku 2001 v likvidaci. I tyto 3 nadace byly ze souboru vyloučeny. Po vyloučení výše zmíněných tří nadací a jednoho nadačního fondu zůstává v souboru 70 organizací.

Analýza výročních zpráv a účetních závěrek poukázala na významné problémy $\mathrm{v}$ transparentnosti některých nadací. Nadace fotbalových internacionálů nezveřejnila na svých webových stránkách ani na portálu portal.justice.cz žádné své výroční zprávy ani účetní závěrky. Nadace Mariastar Humanity zveřejnila výroční zprávu pouze v letech 2009 a 2011 a 
účetní závěrku pouze $\mathrm{v}$ roce 2009 . To vedlo $\mathrm{k}$ tomu, že $\mathrm{v}$ drtivé většině sledovaných kritérií byly zařazeny tyto nadace do kategorie ,nezveřejňuje“. Totéž platí pro Nadaci ARBOR VITAE, která zveřejnila výroční zprávu v letech 2009 až 2012 a nezveřejnila žádnou svou účetní závěrku. Tyto nadace lze označit za nejméně transparentní ze všech př́ijemců př́spěvků z „NIF“. Zároveň je nutné uvést, že Nadace BOHEMIAE, Nadace fotbalových internacionálů, Nadace Mariastar Humanity a Nadace ARBOR VITAE získaly dohromady prostředky v celkové částce 62321 tis. Kč a veřejnost neví, jak bylo s těmito zdroji naloženo. Ani stát nedokázal zajistit nápravu prostřednictvím svých nástrojů, které k tomu má.

Druhý statistický soubor zahrnuje také 70 nadací, tentokrát jde o ostatní nadace bez prostředků z Nadačního investičního fondu, které byly vybrány náhodným výběrem, přičemž aby mohla být nadace zahrnuta do statistického souboru, musela být aktivní ve zveřejňování dokumentů na portálu portal.justice.cz v letech 2009 až 2013 a musela vzniknout v roce 2009 nebo dř́ve. Naopak do výzkumu nebyly zařazeny nadace $\mathrm{v}$ likvidaci.

Přehled ostatních nadací bez prostředků z Nadačního investičního fondu zahrnutých do výzkumu uvádí Tabulka 1.

Tabulka 1: Přehled analyzovaných nadací bez prostředků z Nadačního investičního fondu

\begin{tabular}{|c|c|}
\hline $\begin{array}{l}\text { "Nadace Doktora Leopolda Prečana, arcibiskupa olomouckého, k podporování } \\
\text { Arcibiskupského kněžského semináře v Olomouci" }\end{array}$ & Nadace Masarykovy dělnické akademie \\
\hline "NADACE INGRID WLADUFSENOVÉ" & Nadace města Karlovy Vary \\
\hline "Nadace Východočeská onkologie" & Nadace města Vodňan \\
\hline Nadace AB & Nadace mezilidské tolerance Thomase Grala \\
\hline Nadace ALTEGO & Nadace mezinárodní lékařské pomoci \\
\hline Nadace AMERICAN INSTITUTE FOR FOREIGN STUDY PRAGUE & Nadace MUDr. Václava Náprstka \\
\hline NADACE ARDEA & Nadace Mucha \\
\hline Nadace Astma 2000 - Sanatorium pro astmatické děti & Nadace na ochranu fauny Evropy \\
\hline Nadace AUTOEK - nadace pro rozvoj ekologie v automobilovém průmyslu & Nadace $\mathrm{O} 2$ \\
\hline Nadace B.Jana Horáčka Českému Ráji & Nadace OKD \\
\hline Nadace Bohuslava Martinů & Nadace Per musicam aequo \\
\hline NADACE BONUM COMMUNE & Nadace Pohyb bez pomoci \\
\hline Nadace Collegium Marianum při Společenství Týnské školy Panny Marie v Praze & Nadace Pražské děti \\
\hline Nadace českého kubismu & Nadace PRO FUTURO \\
\hline Nadace českých památek & Nadace pro rozvoj architektury a stavitelství \\
\hline Nadace ČEZ & Nadace Quido Schwanka - Troja, město v zeleni \\
\hline Nadace člověk člověku & Nadace RACEK \\
\hline $\begin{array}{l}\text { Nadace Dra Eduarda Parmy, advokáta ve Frenštátě a jeho manželky Betty Heleny } \\
\text { Parmové }\end{array}$ & Nadace RUDOLF \\
\hline Nadace DrAK Dr. Altenburg Kohl & Nadace SAPIRICON \\
\hline Nadace dřevo pro život & NADACE SENIO \\
\hline Nadace FILM-FESTIVAL KARLOVY VARY & Nadace Sirius \\
\hline Nadace Georgia Agricoly, region Slavkovský les & NADACE SOLIDARITY \\
\hline Nadace HAIMAOM & Nadace Strážné věže \\
\hline Nadace HAMU & NADACE STUDENT \\
\hline Nadace Hieronymus & Nadace SYNOT \\
\hline Nadace Jana Anderse Sládka & Nadace Tat’ány Kuchařové - Krása pomoci \\
\hline Nadace Jana Pivečky & Nadace Terezy Maxové dětem \\
\hline NADACE JARMILY PIŠKANINOVÉ & Nadace The Bakala Foundation \\
\hline Nadace Jaroslava Havlíčka & Nadace THE KELLNER FAMILY FOUNDATION \\
\hline Nadace KAPKY & Nadace Truck HELP \\
\hline Nadace Komerční banky a.s. - Jistota & Nadace Věry a Vladimíra Janouškových \\
\hline NADACE LANGHANS PRAHA & Nadace Věry Třebické Řivnáčové \\
\hline Nadace Leoše Janáčka & Nadace VIA FORTUNA \\
\hline NADACE MACHINERY FUND & Nadace VINCI v České republice \\
\hline Nadace Martina a Lenky Romanových pro PORG & Nadace Železná Opona \\
\hline
\end{tabular}

Zdroj: Vlastní zpracování. 
Analyzována jsou tato kritéria transparentnosti vyplývající z legislativy:

- zveřejňování výroční zprávy,

- zveřejňování účetní závěrky,

- zveřejňování dárců prostředků s částkou nad 10 tis. Kč,

- zveřejňování prŕijemců nadačních prríspěvků s částkou nad 10 tis. Kč,

- zveřejňování zprávy auditora k účetní závěrce, resp. výroční zprávě,

- zveřejňování auditora,

- zveřejňování výroku auditora,

- zveřejňování nákladového pravidla a vyhodnocení jeho plnění,

- zveřejňování statutu,

- zveřejňování grantových pravidel.

V prŕípadě nadací s prostředky z Nadačního investičního fondu jsou sledována navíc ještě tato dvě kritéria, která u skupiny ostatních nadací bez prostředků z Nadačního investičního fondu nenachází opodstatnění:

- zveřejňování zprávy auditora o ověření hospodaření s prostředky $\mathrm{z}$ Nadačního investičního fondu,

- zveřejňování informací týkajících se hospodaření s prostředky z Nadačního investičního fondu.

Tyto požadavky vyplývaly nadacím s prostředky z Nadačního investičního fondu ze smluv o převodu prostředků uzavřených mezi nimi a státem.

\section{Ověření platnosti hypotéz}

Výsledky výzkumu za oba analyzované statistické soubory nadací zachycují Tabulka 2 a Tabulka 3.

Tabulka 2: Shrnutí výsledků - nadace bez prostředků z NIF (počet nadací nezveřejňujících kritérium $\mathrm{v} \%$ )

\begin{tabular}{|l|c|c|c|c|c|}
\hline & $\mathbf{2 0 0 9}$ & $\mathbf{2 0 1 0}$ & $\mathbf{2 0 1 1}$ & $\mathbf{2 0 1 2}$ & $\mathbf{2 0 1 3}$ \\
\hline Výroční zpráva & $5,71 \%$ & $7,14 \%$ & $11,43 \%$ & $10,00 \%$ & $10,00 \%$ \\
\hline Účetní závěrka & $1,43 \%$ & $2,86 \%$ & $1,43 \%$ & $1,43 \%$ & $2,86 \%$ \\
\hline Dárci & $18,57 \%$ & $18,57 \%$ & $17,14 \%$ & $18,57 \%$ & $17,14 \%$ \\
\hline Př́jemci nadačních příspěvků & $17,14 \%$ & $22,86 \%$ & $12,86 \%$ & $21,43 \%$ & $17,14 \%$ \\
\hline Zpráva auditora & $8,57 \%$ & $10,00 \%$ & $11,43 \%$ & $11,43 \%$ & $17,14 \%$ \\
\hline Výrok auditora & $8,57 \%$ & $10,00 \%$ & $11,43 \%$ & $11,43 \%$ & $17,14 \%$ \\
\hline Auditor & $8,57 \%$ & $10,00 \%$ & $11,43 \%$ & $11,43 \%$ & $17,14 \%$ \\
\hline Správní náklady & $47,14 \%$ & $47,14 \%$ & $47,14 \%$ & $50,00 \%$ & $52,86 \%$ \\
\hline
\end{tabular}

Zdroj: Výroční zprávy a účetní závěrky nadací. Vlastní zpracování.

- Na počátku analyzovaného období rostl počet organizací nezveřejňujících výroční zprávu, a to až na $11,43 \%$ v roce 2011.

- Účetní závěrku nezveřejnil nízký počet nadací, větší problém však spočíval v nekompletní účetní závěrce spojené s nezveřejněním př́lohy k ní, což představovalo $17,14 \%$ až $20 \%$ analyzovaných subjektů.

- Dárci nebyli uvedeni ve výroční zprávě ani v účetní závěrce až u 18,57 \% nadací.

- Naopak př́jemce poskytnutých nadačních př́íspěvků nebylo možné dohledat ve zveřejněných dokumentech u 17,14 \% až 22,86 \% sledovaných organizací.

- Zprávu auditora a výrok auditora k účetní závěrce nezpř́stupnilo 8,57 \% až 17,14\% nadací, přičemž tato kritéria vykazovala po celé sledované období rostoucí trend.

- Stejný vývoj mělo i kritérium zaměřující se na zveřejňování auditora. 
- Více než polovina nadací nezveřejnila pravidlo pro omezení správních nákladů a potažmo s tím důsledně nevyhodnocovala dodržování správních nákladů. I toto kritérium vykazovalo rostoucí tendenci.

- Statut nebylo možné dohledat u $20 \%$ organizací a grantová pravidla u 85,71\% (stav k 23. červnu 2017).

Zejména klesající podíl nadací zveřejňujících výroční zprávu, vysoké procento nadací s nekompletní účetní závěrkou, nedostatečné informace o poskytnutých nadačních př́ispěvcích a přijatých darech, rostoucí podíl nadací nezveřejňující zprávu a výrok auditora, velmi vysoký počet nadací s nezveřejněnými grantovými pravidly, pětinový podíl nadací nezveřejňujících statut a výrazný počet nadací nevěnujících se dostatečně řízení správních nákladů, vedou k potvrzení hypotézy 1. Pro její potvrzení svědčí především zákonná povinnost informovat o analyzovaných kritériích uživatele výročních zpráv a účetních závěrek.

Tabulka 3: Shrnutí výsledků - nadace s prostředky z NIF (počet nadací nezveřejňujících kritérium v \%)

\begin{tabular}{|l|c|c|c|c|c|}
\hline & $\mathbf{2 0 0 9}$ & $\mathbf{2 0 1 0}$ & $\mathbf{2 0 1 1}$ & $\mathbf{2 0 1 2}$ & $\mathbf{2 0 1 3}$ \\
\hline Výroční zpráva & $5,71 \%$ & $7,14 \%$ & $4,29 \%$ & $5,71 \%$ & $8,57 \%$ \\
\hline Účetní závěrka & $8,57 \%$ & $11,43 \%$ & $10,00 \%$ & $8,57 \%$ & $12,86 \%$ \\
\hline Dárci & $25,71 \%$ & $21,43 \%$ & $22,86 \%$ & $22,86 \%$ & $22,86 \%$ \\
\hline Př́́jemci nadačních př́spěvků & $5,71 \%$ & $5,71 \%$ & $5,71 \%$ & $7,14 \%$ & $10,00 \%$ \\
\hline Informace o hospodaření s prostředky & $17,14 \%$ & $17,14 \%$ & $17,14 \%$ & $15,71 \%$ & $17,14 \%$ \\
\hline Zpráva auditora pro účely „NIF“ & $40,00 \%$ & $45,71 \%$ & $41,43 \%$ & $44,29 \%$ & $44,29 \%$ \\
\hline Zpráva auditora k účetní závěrce & $5,71 \%$ & $10,00 \%$ & $7,14 \%$ & $8,57 \%$ & $11,43 \%$ \\
\hline Výrok auditora & $5,71 \%$ & $10,00 \%$ & $5,71 \%$ & $7,14 \%$ & $10,00 \%$ \\
\hline Auditor & $5,71 \%$ & $10,00 \%$ & $5,71 \%$ & $7,14 \%$ & $10,00 \%$ \\
\hline Správní náklady & $38,57 \%$ & $37,14 \%$ & $38,57 \%$ & $34,29 \%$ & $35,71 \%$ \\
\hline
\end{tabular}

Zdroj: Výroční zprávy a účetní závěrky nadací. Vlastní zpracování.

- Příjemci př́spěvků z „NIF“ vykazovali zejména v posledních dvou letech sledovaného období nárůst počtu nezveřejněných výročních zpráv. V prvních dvou letech jsou výsledky za obě skupiny totožné, ve zbývajícím období dosáhly nadace s prostředky $\mathrm{z}$ „NIF“ lepších výsledků.

- Výrazně horší hodnoty pak vyšly (ve srovnání s druhou skupinou nadací) v souvislosti s nezveřejněním účetní závěrky, a to v každém analyzovaném roce. Až $30 \%$ nadací nemělo v analyzovaném období kompletní účetní závěrku.

- Obdobně tomu bylo i na úrovni kritéria hodnotícího zveřejňování dárců. Zde vyšly hodnoty horší až o 7 \%.

- Naopak výrazně lépe dopadlo kritérium sledující poskytnuté nadační př́íspěvky.

- Zhruba $16 \%$ až $17 \%$ nadací nevěnovalo dostatečnou pozornost poskytování podrobnějších informací o hospodaření s prostředky z „NIF“.

- Velmi vážné zjištění se týká počtu nezveřejněných zpráv auditora pro účely ověření hospodaření s prostředky „NIF“, kdy až téměř 46 \% nadací v roce 2010 tak neučinilo.

- Lépe na tom byli př́jemci prostředků z „NIF“ v oblasti zveřejňování zprávy auditora k účetní závěrce, avšak ke konci sledovaného období se projevil stejný trend růstu počtu subjektů, které zprávu nezveřejnily, tak jako tomu bylo v prŕípadě nadací bez prostředků z „NIF“. To samé platí pro výrok a zprávu auditora.

- Stejným neduhem v podobě nezveřejnění pravidla omezujícího správní náklady a jeho vyhodnocení a nedostatečné kontroly správních nákladů trpěly rovněž nadace s prostředky z „NIF“, přičemž tato skupina se jevila ve všech sledovaných letech jako transparentnější (zejména v posledních dvou letech o zhruba 15 \% až 17 \%). 
- Povinnost zveřejnit statut nesplnilo 6 prŕjemců př́spěvků z „NIF“ $(8,57 \%$; stav k 31. květnu 2017) a $20 \%$ nadací bez prostředků z „NIF“, což značí podstatně lepší výsledky ve prospěch první jmenované skupiny.

- Grantová pravidla nezveřejnilo 19 nadací s prostředky z „NIF“ (27,14\%; stav k 31. květnu 2017), to je více než čtvrtina analyzovaných organizací. Ve srovnání s druhou skupinou nadací $(85,71$ \%) jde o diametrálně odlišné, avšak lepší hodnoty.

Hypotéza 2 nebyla potvrzena s ohledem na výrazně odlišné závěry spojené se zveřejněním účetní závěrky, zveřejněním dárců a př́jemců nadačních př́íspěvků. Obdobně kritéria zkoumající zveřejnění pravidla omezujícího správní náklady a jeho vyhodnocení, zveřejnění statutu a grantových pravidel vykazovala významné odchylky. Celkově se zdají být nadace s prostředky z „NIF“ transparentnější než ostatní nadace.

Platnost hypotézy 2 je možné ověřit také pomocí Z-testu rovnosti dvou výběrových poměrů. Test předpokládá existenci dvou souboru $\left(\mathrm{S}_{1}\right.$ a $\left.\mathrm{S}_{2}\right)$ velikostí $\mathrm{n}_{1}$ a $\mathrm{n}_{2}$. Soubory jsou tvořeny pozorováními dichotomického znaku. Hodnoty znaku lze označit A a $\mathrm{B}$. Test předpokládá, že se výskyt hodnot znaku v souborech řídí binomickým rozdělením. Necht' se v souboru $\mathrm{S}_{1}$ vyskytuje znak A s četností $\mathrm{p}_{1}$, v soboru $\mathrm{S}_{2}$ pak s četností $\mathrm{p}_{2}$. Test se snaží vyslovovat závěry o platnosti hypotézy, že se relativní četnosti (tj. ,výběrové poměry“) $\pi_{1}=\frac{p_{1}}{n_{1}} a \frac{m_{2}}{n_{2}}$ výskytu znaku A rovnají.

Test binomické rozdělení výskytu znaků aproximuje užitím centrální limitní věty pomocí normálního rozdělení. Pro dostatečnou přesnost aproximace se proto obvykle požaduje splnění podmínky:

$$
\min \{\pi, 1-\pi\} \min \left\{n_{1}, n_{2}\right\} \geq 5 \text {, }
$$

kde $\pi=\frac{p_{1}+p_{2}}{n_{1}+n_{2}}$ je sdružený výběrový poměr. Test rozhoduje podle testové statistiky:

$$
Z_{a b s}=\frac{\pi_{1}-\pi_{2}}{\sqrt{\pi(1-\pi)\left(\frac{1}{n_{1}}+\frac{1}{n_{2}}\right)}},
$$

která má při splnění předpokladů testu přibližně normované normální rozdělení.

Test se provádí pro každé z kritérií a každý sledovaný rok. Za parametry jsou dosazovány následující hodnoty. Velikosti souborů $n_{1}=70$ a $n_{2}=70$ jsou počty nadací s prostředky z NIF a bez prostředků z NIF. Četnosti jednoho ze znaků $p_{1}$ a $p_{2}$ jsou počty nadací vyhovujících podle aktuálního kritéria s prostředky z NIF a bez prostředků z NIF v aktuálním roce.

Testována je hypotéza $H_{0}: \pi_{1}=\pi_{2}$ proti oboustranné alternativní hypotéze $H_{1}: \pi_{1} \neq \pi_{2}$.

Výsledky splnění předpokladu podle (1) uvádí následující Tabulka 4. 
Tabulka 4: Splnění předpokladu

\begin{tabular}{|l|c|c|c|c|c|c|}
\hline & $\mathbf{2 0 0 9}$ & $\mathbf{2 0 1 0}$ & $\mathbf{2 0 1 1}$ & $\mathbf{2 0 1 2}$ & $\mathbf{2 0 1 3}$ & Součet \\
\hline Výroční zpráva & 4 & 5 & 5,5 & 5,5 & 6,5 & 26,5 \\
\hline Účetní závěrka & 3,5 & 5 & 4 & 3,5 & 5,5 & 21,5 \\
\hline Dárci & 15,5 & 14 & 14 & 14,5 & 14 & 72 \\
\hline Př́jemci nadačních příspěvků & 8 & 10 & 6,5 & 10 & 9,5 & 44 \\
\hline Zpráva auditora & 5 & 7 & 6,5 & 7 & 10 & 35,5 \\
\hline Výrok auditora & 5 & 7 & 6 & 6,5 & 9,5 & 34 \\
\hline Auditor & 5 & 7 & 6 & 6,5 & 9,5 & 34 \\
\hline Správní náklady & 30 & 29,5 & 30 & 29,5 & 31 & 150 \\
\hline
\end{tabular}

Zdroj: Vlastní zpracování.

Test se nedá použít pro účetní závěrku v letech 2009, 2011 a 2012 a pro výroční zprávu v roce 2009. U výroční zprávy tato skutečnost nepůsobí problémy, u účetní závěrky je testován součet.

P-hodnoty podle testovacího kritéria (2) uvádí následující Tabulka 5.

Tabulka 5: P-value

\begin{tabular}{|l|c|c|c|c|c|c|}
\hline & $\mathbf{2 0 0 9}$ & $\mathbf{2 0 1 0}$ & $\mathbf{2 0 1 1}$ & $\mathbf{2 0 1 2}$ & $\mathbf{2 0 1 3}$ & Součet \\
\hline Výroční zpráva & 1,000 & 1,000 & 0,116 & 0,346 & 0,771 & 0,005 \\
\hline Účetní závěrka & 0,053 & 0,049 & 0,029 & 0,053 & 0,028 & 0,000 \\
\hline Dárci & 0,309 & 0,673 & 0,398 & 0,532 & 0,398 & 0,000 \\
\hline Př́jemci nadačních příspěvků & 0,034 & 0,004 & 0,145 & 0,016 & 0,217 & 0,000 \\
\hline Zpráva auditora & 0,512 & 1,000 & 0,382 & 0,573 & 0,334 & 0,002 \\
\hline Výrok auditora & 0,512 & 1,000 & 0,227 & 0,382 & 0,217 & 0,000 \\
\hline Auditor & 0,512 & 1,000 & 0,227 & 0,382 & 0,217 & 0,000 \\
\hline Správní náklady & 0,306 & 0,231 & 0,306 & 0,060 & 0,041 & 0,000 \\
\hline
\end{tabular}

Zdroj: Vlastní zpracování.

Podle vyznačených hodnot není možné zamítnout hypotézu $\mathrm{H}_{0}$, jelikož P-value je vždy vyšší než hladina významnosti $(\alpha=0,05)$. Ovšem pokud je testován součet, pak lze $\mathrm{H}_{0}$ zamítnout. Opět se tedy hypotéza 2 nepotvrdila. Na úrovni analyzovaných legislativních kritérií transparentnosti existují mezi oběma skupinami nadací určité rozdíly.

\section{Závěr}

Ve srovnání $\mathrm{s}$ výsledky, $\mathrm{k}$ nimž dospěly jiné výzkumy a studie, lze $\mathrm{v}$ rámci kritéria zveřejňování výroční zprávy spatřit výrazné rozdíly. Citované výzkumy a studie uvádí interval $40 \%$ až $50 \%$ nadací zveřejňujících výroční zprávu. Důvodem může být náhodný výběr analyzovaných souborů nadací nebo také fakt, že došlo v této oblasti opravdu ke značnému zlepšení, jelikož výzkum provedený v tomto článku dospěl zhruba k hodnotě $90 \%$ u obou skupin nadací.

Webové stránky patří mezi dominantní komunikační nástroj nadací s př́íspěvky z „NIF“, jelikož s výjimkou jedné nadace provozují všechny svůj web. U nadací bez prostředků $z$ „NIF“ dospěl výzkum k obdobným hodnotám jako citované výzkumy, což znamená, že zhruba polovina nadací nemá své webové stránky.

Povinnost zveřejnit statut nesplnilo 6 prŕijemců příspěvků z „NIF“ $(8,57 \%)$ a 20 \% nadací bez prostředků z „NIF“. Oproti tomu zmíněné výzkumy hovoří o dvou třetinách nadací neplnících povinnost zveřejnit statut, což je v rozporu s výsledky výzkumu provedeného $\mathrm{v}$ tomto článku. Důvodem může být náhodný výběr souboru nadací. 
Grantová pravidla nezveřejnilo 19 nadací s prostředky z „NIF“ $(27,14 \%)$, což je více než čtvrtina analyzovaných organizací. Ve srovnání s druhou skupinou nadací $(85,71 \%)$ jde o diametrálně odlišné, avšak lepší hodnoty. Pouze hodnoty nadací s prostředky z „NIF“ se pomalu blíží závěrům jiných výzkumů, které uvádí 36,4 \%. Nadace bez prostředků z „NIF“ vykazují naopak výrazné rozdíly.

Informace o přijatých darech nezveřejnilo dle jiných vědeckých prací asi $40 \%$ nadací. To je rozdíl v porovnání $\mathrm{s}$ nadacemi s prostředky $\mathrm{z}$ „NIF“ (až 25,7 \%) a nadacemi bez těchto prostředků (až 18,6 \%) viz výzkum provedený v tomto článku. Stejně jako autor tohoto článku upozorňují také další autoři na dosti nesrovnatelné hodnoty uváděné v souvislosti se zveřejňováním informací ohledně přijatých darů a poskytnutých nadačních příspěvků, kdy některé nadace vykazují nadprůměrné hodnoty a jiné neuvádějí nic.

Výzkum nepotvrdil vysoký podíl nadací nezveřejňujících informace o nákladovém pravidle (až 89,1\%), o němž hovoř́i citované vědecké práce, jelikož dospěl k hodnotám u nadací „NIF“ na úrovni 38,6 \% a u ostatních nadací ve výši 52,9 \%.

Rozdíly panují také v oblasti zveřejňování informací o provedeném auditu v podobě zprávy a výroku auditora k účetní závěrce a výroční zprávě. Vědecké práce uvádí, že pouze 30,9 \% nadací zveřejňuje informace o provedeném auditu. Výzkum provedený v tomto článku dospěl k hodnotám pohybujícím se u obou skupin organizací nad $80 \%$.

V posledních letech dochází v Evropě na poli nadačního práva ke značné liberalizaci, zejména pokud jde o účel nadace, privatizaci dohledu nad nadacemi, rozšiřování možností podnikání a zpř́ínňování pravidel pro vnitřní organizaci nadací (tzv. corporate governance; Ronovská 2012 a Ronovská 2015). V současné době nabývá dohled nad nadacemi v jednotlivých zemích různých podob, lze však říci, že postupně upadá dohled ze strany státu a důraz je kladen spíš na prevenci pochybení ze strany orgánů nadací (zesílení odpovědnosti řídících orgánů nadace). Obdobný vývoj lze spatřit i v České republice s ohledem na novou právní úpravu v podobě Nového občanského zákoníku.

Není pochyb o tom, že legislativa by měla pružně reagovat na aktuální potřeby nadací a zajistit jim co nejlepší podmínky pro jejich činnost. Zejména co se týká možnosti změnit statut, účel nadace apod. Nejeví se proto jako př́liš št'astné uvolňovat celou právní úpravu nadací formou zrušení zmíněného Zákona o nadacích a nadačních fondech a vytvoření nového předpisu. Vhodné je spíše částečné zmírnění v oblasti možnosti změnit účel nadace a statut, umožnit nadacím podnikat apod. Zdá se, že cílem nové legislativy není zvýšit úroveň transparentnosti českých nadací, když i přes její nízkou míru před přijetím nové právní úpravy nadací v roce 2014 došlo k výraznému uvolnění legislativních požadavků kladených na nadace. Právní úprava by na ni však myslet měla, zejména pokud jde o průhledné hospodaření těchto neziskových organizací a jejich možné zneužití k financování terorismu a legalizaci výnosů z trestné činnosti. Otázky zavádění černých listin neziskových organizací se dotýká např. Vymětal (nedatováno, a), přičemž cestu k posílení transparentnosti na úrovni celého neziskového sektoru nebo alespoň některých jeho složek vidí Vymětal (nedatováno, b) v jeho samoregulaci. Dvořák (nedatováno) řadí mezi objektivní aspekty zvyšující míru bezpečnostního rizika zejména benevolentní legislativu, neexistenci ověření účetní závěrky auditorem, nesestavení a nezveřejnění účetní závěrky, snadnost založení neziskové organizace aj. Pokud však není vůle zákonodárce současnou právní úpravu měnit, je možné vyjít z aktuální podoby Nového občanského zákona, jenž některé požadavky na transparentnost převzal z předchozího Zákona o nadacích a nadačních fondech, avšak stát by měl dohlížet na 
jejich důsledné plnění. V opačném případě by se neměl bát ukládat sankce. I tak je možné zvyšovat transparentnost, aniž by musel být významným způsobem měněn současný zákon.

Zároveň se změnou legislativy došlo ve stejném roce 2014 k ukončování smluv o převodu prostředků z Nadačního investičního fondu nadacím, což s sebou přineslo značnou volnost při nakládání s těmito prostředky, a to i přesto, že téměř polovina prŕijemců nezveřejnila př́slušnou zprávu auditora. Ani zde se tedy nejeví jako př́liš vhodné takto výrazně zmírňovat požadavky kladené na nadace v oblasti transparentního hospodaření. Jistě by stálo za zvážení vrátit se u těchto nadací $\mathrm{k}$ povinnosti auditu hospodaření s prostředky $\mathrm{z}$ „NIF“ nebo zavést povinnost zasílat každoročně zprávu o hospodaření s těmito prostředky Ministerstvu financí jako poskytovateli zdrojů.

\section{Poděkování}

Tento článek je jedním z výstupů grantového projektu „Empirická racionalizace zásadních změn $\mathrm{v}$ evropské auditorské legislativě $\mathrm{z}$ pohledu auditorské profese $\mathrm{v}$ ČR (se zaměřením na vzdělávání v oblasti auditu, kvalitu auditu a problematiku oligopolu na auditorském trhu)“ evidovaného Interní grantovou agenturou VŠE v Praze pod číslem 33/2015.

\section{Literatura}

[1] BACHMAN, P., 2012. Transparentnost organizací občanské společnosti. Hradec Králové: Gaudeamus. ISBN: 978-80-7435-235-5.

[2] DVOŘÁK, V., nedatováno. Hrozba financování terorismu prostřednictvím neziskového sektoru [on-line]. Ministerstvo vnitra České republiky. [vid. 27. ř́jna 2017]. Dostupné z: http://www.mvcr.cz/soubor/studie-dvorak-pdf.aspx.

[3] JAKUBKA, Z., 2006. Proč transparentnost neziskových organizací. In: KROUPA, J. Transparentnost. Sborník k přiležitosti konference v rámci programu ,,Transparency of Procedures at Local Level “, 26. - 27. řijna 2006. Ústí nad Labem: Podnos. ISBN 80239-7873-X.

[4] JOŠT, M., 2016a. Transparentnost hospodaření př́iemců př́íspěvků z Nadačního investičního fondu. Český finanční a účetní časopis, 11(2), 93-108. ISSN: 1802-2200.

[5] JOŠT, M., 2016b. Účetnictví a audit nadací a nadačních fondů po rekodifikaci práva. In: Nové trendy 2016. 11. ročník mezinárodní vědecké konference. Soukromá vysoká škola ekonomická Znojmo. $\quad$ s. $\quad 91-100 . \quad$ ISSN: 2336-7431. Dostupné z: http://trendy.svse.cz/uploads/File/VaV/sbornik_2016.pdf.

[6] JOŠT, M., 2016c. Audit v českých nadacích. GRANT journal, 5(2), 22-25. ISSN: 1805$062 X$.

[7] NEZISKOVKY.CZ, 2017. Statistika počtu nestátních neziskových organizací 2014 $2017 \quad$ [on-line]. [vid. 25. srpna 2017]. Dostupné z: http://www.neziskovky.cz/data/Statistika\%20po\%C4\%8Dtu\%20nest\%C3\%A1tn\%C3\% ADch\%20neziskov\%C3\%BDch\%20organizac\%C3\%AD\%202014_2016_duben2017txt1 6852.pdf.

[8] POSPÍŠIL, M., 2006. Jak zahájit debatu o transparentnosti? [online]. Centrum pro výzkum neziskového sektoru. [vid. 10. srpna 2017]. Dostupné z: http://www.ecvns.cz/?typ=konferencni_prispevky\&publikace=71\&presenter=Publikace.

[9] PROUZOVÁ, Z., 2015. Data a fakta o neziskovém sektoru v ČR [online]. Rada vlády pro nestátní neziskové organizace. [vid. 15. července 2017]. Dostupné z: 
http://www.vlada.cz/assets/ppov/rnno/dokumenty/studie_prouzova_data_a_fakta_o_nezi skovem_sektoru_1.pdf.

[10] RONOVSKÁ, K., 2012. Nové české nadační právo vevropském srovnání. Praha: Wolters Kluwer. ISBN: 978-80-7357-972-2.

[11] RONOVSKÁ, K. a kol., 2015. Metamorfózy nadačního práva v Evropě a České republice na počátku 21. století. Brno: Masarykova univerzita, Právnická fakulta. Spisy Právnické fakulty Masarykovy univerzity, řada teoretické, sv. č. 510. ISBN: 978-80-2107747-8.

[12] STRÁNSKÝ, J., 2007. Transparentnost a výkaznictví v českých nadacích [on-line]. Ministerstvo vnitra České republiky. [vid. 8. července 2017]. Dostupné z: http://www.mvcr.cz/soubor/studie-stransky-pdf.aspx.

[13] STRÁNSKÝ, J., 2009. Měření výkonnosti nestátních neziskových organizací. Disertační práce. Vysoká škola ekonomická v Praze.

[14] VAJDOVÁ, T., 2005. Česká občanská společnost 2004: po patnácti letech rozvoje. Zpráva projektu CIVICUS Civil Society Index pro Českou republiku. Brno: Akademické nakladatelství CERM. ISBN: 80-7204-379-X.

[15] VYMĚTAL, P., nedatováno a). Černé listiny [on-line]. Ministerstvo vnitra České republiky. [vid. 27. ř́ijna 2017]. Dostupné z: http://www.mvcr.cz/soubor/studie-vymetalblackliting-pdf.aspx.

[16] VYMĚTAL, P., nedatováno b). Samoregulace v neziskovém sektoru - nenaplnitelný ideál? [on-line]. Ministerstvo vnitra České republiky. [vid. 27. ř́jna 2017]. Dostupné z: http://www.mvcr.cz/soubor/studie-vymetal-ideal-pdf.aspx.

[17] WYATT, M., nedatováno. Jak spravovat nevládní neziskové organizace: Správní rady a predsednictva. Budapest: The European Center for Not-for-Profit Law. ISBN: 963-216963-8. 